\title{
Leopold Tyrmand. Dziennik pisarza: autokreacja i powieść
}

DOI: 10.19195/2083-7763.7.15

\section{Wstęp}

Zofia Starowieyska-Morstinowa, snując w swoich wspomnieniach refleksję o związku wielkich powieści z przeżyciami ich autorów, zanotowała:

długoletnie doświadczenie recenzenckie nauczyło mnie, że ludzie prawie zawsze piszą o sobie. Doskonale określił to Steinbeck w przedmowie do Na wschód od Edenu. Powiada tam, że jego dzieło jest pudełkiem, w które wkłada wszystko. Takimi pudełkami są - w moim przekonaniu - wszystkie książki świata, oczywiście te, które się liczą. Uważnie czytając można się z nich dowiedzieć „wszystkiego o autorze”; można poznać jego myśli, tęsknoty, obawy i marzenia, często nawet fakty z jego życia. Przeinaczone, przebrane, zakamuflowane, ale dla wprawnego oka rozpoznawalne. Tym przebraniem bywa najczęściej powieść. I wydaje się, że jest to przebranie najlepsze ${ }^{1}$.

Myśl Zofii Starowieyskiej-Morstinowej można odwrócić i znaleźć dzienniki pisane nie do szuflady, a z myślą o publikacji, które są jednocześnie diariuszem i fikcją literacką, zapisywaniem codzienności i pasjonującą powieścią. Taki przypadek to Dziennik 1954 Leopolda Tyrmanda, barwnej postaci środowiska artystyczno-kulturalnego pierwszej i drugiej peerelowskiej dekady, pisarza, dziennikarza, publicysty, niedoszłego architekta, bikiniarza, dandysa, kontestatora politycznego, miłośnika kobiet i propagatora jazzu. Jako pisarz Tyrmand zasłynął przede wszystkim bestsellerową powieścią o chuligańsko-przestępczej Warszawie Zly ${ }^{2}$ i Dziennikiem 1954, wydanym po latach najpierw w Londynie ${ }^{3}$, a później

1 Z. Starowieyska-Morstinowa, Patrzę i wspominam, Kraków 1982, s. 10.

2 L. Tyrmand, Zly, Warszawa 1955.

3 L. Tyrmand, Dziennik 1954, Londyn 1980. Cytaty z tego wydania oznaczone są w tekście DL i numerem strony. 
dopiero w Polsce ${ }^{4}$. Od połowy lat sześćdziesiatych XX wieku z powodu wyjazdu za granicę i decyzji o emigracji przestał być drukowany w kraju i powoli zniknął ze świadomości Polaków. Poważnych opracowań monograficznych dotyczących swojej twórczości, potraktowanej całościowo ${ }^{5}$ bądź też fragmentarycznie ${ }^{6}$ Tyrmand doczekał się dopiero kilkanaście lat po śmierci (zmarł 19 marca 1985 roku w Fort Myers na Florydzie).

Celem tego tekstu jest analiza Dziennika 1954 - przedstawiony zostanie zarówno aktualny stan badań na temat tego dziennika, jak i recenzje współczesnych Tyrmandowi krytyków literackich. Wszyscy badacze i publicyści wskazują na literackość i wartość artystyczną diariusza. W toku analizy pokazana zostanie propozycja czytania dziennika jako powieści, na którą składa się: autokreacja, bohaterowie (autentyczne postaci świata artystycznego) i występujący wątek kobiecy. Leopold Tyrmand świadomie konstruuje opowieść o sobie; jego dziennik z jednej strony staje się powieścią, a z drugiej sam autor nadaje literacki kształt swojemu życiu.

\section{Dziennik 1954 w oczach krytyków}

Dzienniki, autobiografie, diariusze i inne utwory zaliczane do literatury dokumentu osobistego mają swój temat, zanurzone są w kontekście historycznym, mają oryginalny styl, a Roman Zimand ${ }^{7}$ te cechy łączy w jedno i nazywa nadmiarem. Jest to cecha charakterystyczna dla danego dzieła, coś, na czym się skupiamy, odczytując dany zapis wspomnień i przeżyć, coś, co najbardziej przykuwa naszą uwagę. Może to być powtarzający się wątek z życia, styl, zabieg stylistyczny, myśl, do której autor często nawiązuje. Nadmiar dostarcza nam najważniejszych informacji, jakie zawiera dokument osobisty (jeżeli np. są to wydarzenia historyczne, których uczestnikiem bądź obserwatorem jest autor) lub najbardziej istotnych określeń, jakimi możemy dane dzieło opisać (np. figura stylistyczna, motyw czy typ obrazowania). W pewnym sensie rzeczony nadmiar jest jednym $\mathrm{z}$ istotnych elementów konstytuujących i wyróżniających dany dokument jako osobisty.

Co jest zatem owym nadmiarem w przypadku Dziennika 1954? Wielu badaczy zwraca uwagę na ogólny obraz Polski lat stalinizmu ${ }^{8}$, inni poddają badaniom

4 L. Tyrmand, Dziennik 1954, wersja oryginalna, wstęp H. Dasko, Warszawa 1999. Cytaty z tego wydania oznaczone są w tekście DO i numerem strony.

5 Zob. J. Pasterska, Świat wedtug Tyrmanda, Rzeszów 2000; I. Iwasiów, Opowieść i milczenie. O prozie Leopolda Tyrmanda, Szczecin 2000; M. Kowalczyk, Tyrmand karnawałowy, Kraków 2008.

6 Zob. R. Przybylski, O tym jak Leopold Tyrmand wałęsat się w świecie kultury popularnej, Poznań 1998; W. Forajter, „Zły” Tyrmanda jako literatura środka, Kraków 2007.

7 R. Zimand, Diarysta Stefan Ż., Warszawa 1990, s. 26-30.

8 Zob.np.M. Czermińska, Leopold Tyrmand-głosświadka, „Rocznik Towarzystwa Literackiego im. Adama Mickiewicza" 1993, s. 77-83; M. Kowalczyk, Poetyka karnawału w Dzienniku 1954 Leopolda Tyrmanda, „Pamiętnik Literacki” 2006, z. 4, s. 51-70. 
dwie wersje dziennika (londyńską, zredagowaną i przygotowaną do druku przez samego Tyrmanda, oraz tzw. oryginalną, opracowaną przez Henryka Dasko na podstawie rękopisu, która ukazała się już po śmierci autora) ${ }^{9}$, jeszcze inni koncentrują się na zagadnieniu narracji i konstrukcji dziennika oraz jego związków z gatunkiem, jakim jest powieść ${ }^{10}$. Jak zauważył jeden z recenzentów: „Każdy pisarz drukujący za życia podobne dzieło, stylizuje je do tego stopnia, że właściwie przestaje ono być dziennikiem sensu stricto, a staje się opowieścią autobiograficzną. Taką właśnie powieścią faktograficzną, bujną narracyjnie i skrajnie subiektywną jest Dziennik 1954"11. Jeszcze inaczej komentuje Marcin Kowalczyk: „[p]rzewrotnie rzec można, iż właśnie dzięki uwarunkowaniom społecznym, które uniemożliwiły tworzenie literatury, został napisany utwór o większej wartości artystycznej niż większość późniejszych dokonań pisarza"12.

Michał Głowiński w artykule Powieść a dziennik intymny ${ }^{13}$, porównując diariusz z powieścią stylizowaną na dziennik, wymienia trzy najważniejsze obszary problemów dotyczących tego zagadnienia: sens globalny wypowiedzi, politematyczność dziennika i monotematyczność powieści oraz rolę dziennika w życiu ich autorów. Zdaniem badacza powieść zawsze ma założony z góry przez autora sens, ponieważ jest całością, zorganizowaną według określonych zasad. Inaczej sprawa przedstawia się z dziennikiem, poszczególne zapisy mogą nie mieć ze sobą związku, a jeśli nawet mają, to nie muszą prowadzić do skonstruowania całości. Można powiedzieć, że dziennik zawsze będzie kompozycją otwartą, a powieść — zamkniętą. W przypadku Tyrmanda zasadnym wydaje się analiza jego diariusza pod kątem stylizacji powieściowej, uwzględniającej pierwszy obszar problemów wyróżnionych przez Głowińskiego (globalny sens wypowiedzi). Dziennik 1954 uzyskał pewną ramę kompozycyjną i to w obu wydaniach. Zaczyna się wzniosłą inwokacją do Boga:

Rano jeszcze raz ukorzyłem się przed Bogiem. W imię Boże rozpoczynam ten dziennik, jak zawsze to robię z racji świąt, początków, rocznic i innych powodów do metafizycznych

9 Zob. np. K. Niciński, Dwie wersje „Dziennika 1954” Leopolda Tyrmanda. Wokót problemu tożsamości tekstu, „Pamiętnik Literacki” 2006, z. 4, s. 71-94; A. Kochańczyk, Kłamstwo w dzienniku. O „Dzienniku 1954” Leopolda Tyrmanda, [w:] Literatura i komunikacja. Od listu do powieści autobiograficznej, red. A. Blain, Z. Maciejewski, Lublin 1998, s. 192-209.

10 Zob. M. Woźniakiewicz-Dziadosz, Dokument osobisty wobec formy powieściowej („Dziennik 1954" Leopolda Tyrmanda), [w:] eadem, Obrzeża formy powieściowej, Lublin 1998; A. Zawrzykraj, „Dziennik 1954” Leopolda Tyrmanda. Narracja jako narzędzie autokreacji, „Teksty Drugie” 2002, nr 1/2, s. 235-253; Michał Głowiński jednoznacznie zalicza Dziennik 1954 Tyrmanda do diariuszy, które są samodzielną i konsekwentną konstrukcją literacką, zob. M. Głowiński, Dzienniki z minionych lat, [w:] idem, Skrzydła i pięta, Kraków 2004, s. 169.

11 M. Morski, Pomiędzy paszkwilem a pamfletem, „Dziš” 1991, nr 8, s. 165.

12 M. Kowalczyk, op. cit., s. 85.

13 M. Głowiński, Powieść a dziennik intymny, [w:] idem, Narracje literackie i nieliterackie. Prace wybrane, t. II, Kraków 1998. 
sentymentów, rozrzewnień i w ogóle przy każdej okazji, jaka się do tego nadaje. Okazje są dwie. Data. I — w imię Boże, zacznijmy wreszcie ten dziennik! (DO, s. 35).

Trochę bardziej skomplikowane wydaje się zakończenie, albowiem w wydaniu londyńskim dziennik kończy się wpół zdania: „fundamentalizm wejrzeń w samego siebie, niemniej jednak..." (DL, s. 475), sugerując kompozycję otwartą, charakterystyczną dla dziennika, jednak wersja opracowana przez Henryka Dasko kończy się mocnym stwierdzeniem: „[j]edno wiem na pewno - nigdy w życiu, o ile wiem, nie wyrządziłem żadnemu człowiekowi krzywdy" (DO, s. 314). Okazuje się, że tekst został poddany gruntownej redakcji. Co prawda Tyrmand we wstępie wyjaśnił: „niniejsza książka zawiera całość dziennika, nie naruszoną przez względy edytorskie, rozterki moralne, polityczne konieczności, towarzyskie koncesje" (DL, s. 8). Jednak dawać mu całkowitą wiarę byłoby naiwnością, zwłaszcza, że Henryk Dasko w wydaniu oryginalnym, opracowanym przez siebie $\mathrm{z}$ rękopisu, relacjonuje:

Dziennik 1954 rzeczywiście powstał w Polsce, ale został przez autora poddany gruntownej redakcji. Fragmenty maszynopisu Dziennika, zachowane w archiwum Tyrmanda, noszą ślady trzykrotnej obróbki autorskiej. Zamieszczone przez Tyrmanda we wstępie zdanie o „nienaruszalności tekstu" mija się z prawdą, albowiem zmiany poczynione w Dzienniku były zarówno znaczne, jak i znaczące ${ }^{14}$.

Możemy zatem stwierdzić, że po takich zabiegach diariusz stał się w pełni świadomą, założoną i domkniętą kompozycją, uzyskując tym samym globalny sens wypowiedzi. Wspomina o tym sam Tyrmand: „Ale pojawienie się elementu selekcji stawia pisanie to [dziennika - przyp. H.J.R.] w rzędzie literackiej organizacji tekstu"? (DO, s. 36), a tezę o zamierzonej literackości diariusza potwierdzają wszyscy badacze. Aby przytoczyć kilka opinii - A. Zawrzykraj: „[n]ie twierdzę, że Dziennik 1954 jest powieścią stylizowaną na dziennik. Ten tekst wyszedł jednak spod pióra pisarza, który w istniejącej sytuacji politycznej nie mógł publikować i choć nie mógł też zakładać, że ta sytuacja zmieni się w najbliższych dziesięcioleciach, trudno przypuścić, by całkiem pogrzebał myśl o czytelniku"15, Maria Woźniakiewicz-Dziadosz: „[w]ypada jednak zwrócić uwagę na fakt, że zwierzenia Tyrmanda, poza odniesieniami do rzeczywistości, podporządkowane są także zamysłowi literackiemu” ${ }^{16}$ oraz Marcin Kowalczyk: „[z]naczy to, iż rzeczywista sytuacja Tyrmanda-pisarza miała niebagatelny wpływ na formę pisanego utworu. Powstał bowiem tekst, który, mieszcząc się w poetyce gatunku, był jednocześnie samodzielną i przemyślaną konstrukcją literacką"17.

\footnotetext{
${ }^{14}$ H. Dasko, Wstęp, [w:] L. Tyrmand, op. cit., wersja oryginalna, s. 4.

15 A. Zawrzykraj, op. cit., s. 248.

16 M. Woźniakiewicz-Dziadosz, op. cit., s. 57.

17 M. Kowalczyk, Tyrmand karnawałowy..., s. 83-84.
} 


\section{Autokreacja w dzienniku}

Na autokreację w Dzienniku 1954 Leopolda Tyrmanda składają się liczne fragmenty autorefleksyjne. Mają one różny wydźwięk — od deklaracji uczciwego opisania swojego życia, co ciekawe znajdującego się np. na końcu Dziennika, pod datą 2 kwietnia czytamy: „[o]d pierwszej chwili, od samego początku, gdy zacząłem pisać ten dziennik, postanowiłem przedstawić się, czyli opisać siebie możliwie bezstronnie i dokładnie" (DO, s. 308) przez wzniosłą deklarację w jednym z wczesnych zapisów datowanych na 8 stycznia:

Nie mam żadnych danych, aby wierzyć, że życie moje i to, co noszę w sobie, przyniesie kiedykolwiek i komukolwiek jakąś korzyść. Ani mnie, ani ludziom. A mimo to postanowiłem być wiernym noszonej w sobie prawdy i umiłowanym walorom, być wiernym samemu sobie za wszelką cenę. To daje jakąś gorzką satysfakcję (DO, s. 56),

aż po afirmację witalności: „[c]hcę żyć. Życie oznacza dla mnie moją pracę. Życie - to pełny udział w epoce, to kształtowanie swojego czasu, to tworzenie i zostawianie po sobie ludzkich wartości - dzieci, książek, wspomnień, ulepszeń" (DO, s. 208). Na kartach diariusza znajdziemy także wyznania trochę mniejszego kalibru, dotyczące cech charakteru i upodobań autora:

Długo i zajadle sprzątałem pokój. Lubię porządek. Ponadto daję się ponieść sentymentom i sprzątam wypełniony wspomnieniami. [...] Tak tedy sprzątam z łezką. A potem odczuwam ostre ukłucie w sercu, gdy odwiedzający mnie goście błocą podłogę. Instynkt sprzątającego gra we mnie pobudkę i wzywa mnie do walki. Goście to wyczuwają i potulnie posuwają się na szmatach (DO, s. 123)

lub nadzwyczajnych umiejętności, np. tańca:

Tańczę dobrze boogie-woogie. Za młodych lat, zagranicą, amerykańscy żołnierze potrafili robić mi owacje, kiedy, złapawszy dobrą partnerkę, pokazywałem w pełni, na co mnie stać w dziedzinie jazzu i swingowej choreografii. Teraz też nie mogło być inaczej. Wprawdzie dziewczyna była drewniana, ale to mi nie przeszkadzało, na jej tle wychodził mój kunszt z młodych lat tak właśnie, w jakim stopniu był w tej chwili potrzebny. Chłopcom oczy wyszły na wierzch z podziwu (DO, s. 128).

Autoanaliza tekstu dziennika dotyczy raczej trudności samego pisania, poczyniona już na samym wstępie:

Jakże trudno jest pisać dziennik. W nikim, kto się do tego nie brał, nie może skrystalizować się pojęcie tych trudności. Dopiero chęć i zamiar takiego pisania, zmierzone noniuszem możliwości i umiejętności, dają w rozliczeniu rzut oka i wgląd w owe trudności. Jest to przy tym wgląd perspektywiczny, zacierający złożoność koniecznego do przezwyciężenia szczegółu (DO, s. 35).

Równie ważna jest odpowiedź udzielona samemu sobie, wyjaśniająca sens pisania dziennika jako próbę ocalenia czegoś:

Tak, chodzi o to, o świadectwo dla samego siebie, o wystawienie świadectwa memu życiu, moim pragnieniom i myślom, mojej epoce, z którą jestem związany nieskończonością węzłów. Ma 
to być świadectwo z pierwszej ręki, złożone przez stosunkowo najlepiej zorientowanego w danej sprawie świadka (DO, s. 36).

Cel szczytny, chociaż wydaje się, że zapis dla samego siebie nie był koniecznością, Tyrmandowi bardziej chodziło o przyszłego czytelnika i pozostawienie świadectwa przyszłym pokoleniom, bo chęć publikacji jest immanentnie wpisana w dziennik, komunikowana niemal od pierwszego zdania. Z upływem czasu rola diariusza rosła. Oprócz zapisu czasów codzienne notatki stały się dla Tyrmanda również świadomą protezą literatury:

Ten dziennik jest namiastką. Namiastką twórczości. Jest moim usprawiedliwieniem wobec samego siebie, a nie czymś oryginalnym, konstruktywnym, czymś, z czego mógłbym być dumny. I to wcale nie jestem ja. Ja mógłbym siebie wyrazić albo w dziele, albo w działalności. I jedno, i drugie jest mi teraz odmówione (DO, s. 55).

I rzeczywiście - kiedy tylko Tyrmand podpisał umowę na napisanie Złego, dziennik wylądował w szufladzie, ale zanim to nastąpiło, pisarz zdążył się już więcej niż przyzwyczaić do czynionych dzień po dniu notatek: „Ja już trochę ten dziennik kocham za jego ułomność, niepełność, za satysfakcję grzebania się w nieprzewidywalnym" (DO, s. 112). Mało tego, przez systematycznie sporządzane zapiski w życiu Tyrmanda zapanował pewien ład twórczy, który pozwolił uwolnić się od myśli o zmarnowanym życiu:

W ogóle - dzień mój wygląda nader dziwnie. Jedno jest pewne: utraciłem mdlące poczucie tracenia czasu, marnowania dnia, czasu przepływającego między palcami, każdy dzień jest przesycony pisaniem dziennika, myślami o dzienniku i jego przyszłych losach, zawiera w sobie pracę i dokonywanie czegoś. Powiem bez przesady, że dziennik stał się rodzajem katalizatora mego życia psychicznego (DO, s. 182).

Pomimo największych wątpliwości, praca nad dziennikiem ocalała pisarza przed kompletnym zwątpieniem, depresją, pisanie nadawało życiu sens:

Po co pisać, kiedy nie wierzę ani w trwałość, ani w sens, ani w przydatność mojego pisania? Po co pisać, kiedy przeżywanie jest ważniejsze, najważniejsze, a czas zużyty na pisanie wydarty jest przeżywaniu... Zasypiając, wiedziałem, że muszę, wiedziałem na pewno, że nazajutrz, z samego rana, zwlokę się z tóżka i napiszę to wszystko" (DO, s. 269-270).

\section{Postaci (bohaterowie) w dzienniku}

Mocną stroną Dziennika 1954 są zawarte w nim portrety i charakterystyki ludzi, których Tyrmand znał, czasem się z nimi przyjaźnił, niektórych nie lubił albo im zazdrościł umiejętności ustawienia się w komunistycznej rzeczywistości, ale wszystkie one opisane są z niezwykłym pisarskim talentem i mogłyby pełnić rolę szkicu bohaterów literackich. Przytoczmy kilka przykładów. Tak oto Tyrmand opisuje Kazimierza Koźniewskiego, pisarza, publicystę, autora około 50 książek i 6000 artykułów, historyka harcerstwa, autora scenariuszy filmowych, dziennikarza „Przekroju” i „Polityki”, w 1952 roku laureata nagrody państwowej: 
Obiad jadłem w Klubie Literatów z przypadkowo spotkanym Koźniewskim. Ten człowiek nie zmienia się wcale, jest zawsze taki sam - żywy i żywotny, tęgawy blondyn w okularach, z karkiem młodego, niemieckiego rzeźnika i z różowiejącą łysiną, naładowany energią, hałasem, szybkimi słowami, inteligencją, egoizmem, zdawkową szlachetnością, hura pozytywistycznością, ze wszystkiego zadowolony, zawsze bardzo dobrze poinformowany [...] (DO, s. 45).

Koźniewski należy właśnie do tych, którzy świetnie sobie w nowej rzeczywistości radzą, choć wcale nie są wybitni czy nadmiernie utalentowani:

Rozmawialiśmy z Kaziem obficie, gdyż jest to plotkarz dużego kalibru i wysokiego lotu. Doskonały dziennikarz, który — niestety - ubrdał sobie, że jest pisarzem. W warunkach obecnych Kazik, z dziennikarskim, instynktownym wyczuciem potrzeby chwili, produkuje ,literaturę", za którą otrzymuje odznaczenia i nagrody. Bóg z nim (DO, s. 123).

Z kolei Koźniewski po latach i po opublikowaniu Dziennika 1954 tak komentuje pisarstwo Tyrmanda: „—Dlaczego taki dobry jest Filip? — pyta Koźniewski. — Bo tam prawie nic się nie dzieje, są za to świetne opisy. Dlatego właśnie najlepszą powieścią Tyrmanda jest Dziennik..."18 . Już po śmierci Koźniewskiego, która miała miejsce w 2005 roku, okazało się, że w swej podejrzliwości wobec kolegów i ich bacznemu przyglądaniu się Tyrmand miał rację. W artykule Konfident $z$ wybo$r u^{19}$, opublikowanym w czasopiśmie „Wprost”, autorzy demaskują Koźniewskiego jako wieloletniego współpracownika UB i SB (współpraca zaczęła się jeszcze w latach czterdziestych XX w. i trwała aż do 1989 roku).

Natomiast pikantnie, a zatem atrakcyjnie z punktu widzenia czytelnika wygląda konfrontacja Tyrmand-Kałużyński, w Dzienniku czytamy:

Zygmunt Kałużyński jest mocno zbudowanym brunetem o twarzy rozradowanego szympansa. Uśmiech ma miły, młodą łysinę na pokaz, ubiera się z niedbałością bliską kabotyństwa w totalnie zagraniczne ciuchy. Nazwisko dobre i autentyczne, żadnych wojennych pseudonimów (DL, s. 74).

Jak widać, do złośliwego portretu Tyrmand dodaje jakiś sympatyczny element, co łagodzi obraz opisywanej postaci. Jednak Zygmunt Kałużyński kompletnie nie docenił tego zabiegu i Mariusz Urbanek zanotował jego ripostę, niemającą w sobie ani odrobiny finezji: „[w]ymysły Tyrmanda. Postąpił jak pisarz, który bierze jakąś postać z rzeczywistości i tworzy z niej całkowicie kogoś innego. A on w swoim zwierzęcym antykomunizmie potrafił rozdawać tylko cenzurki” ${ }^{20}$. Cenzurki mogą być też pozytywne, np. o Zbigniewie Herbercie czytamy:

Jest to jeden z najwybitniejszych moich współczesnych. Moim zdaniem, jest największym poetą młodego pokolenia powojennej Polski. [...] Oprócz wielkiego talentu nosi w sobie nie mniejszą, arcyrzetelną erudycję i nieprzeciętną inteligencję, co razem składa się na rzadką, wybitną indywidualność. [...] Czystość moralna i wierność samemu sobie są busolą życia tego człowieka. Oczywiście, klepie biedę przykładową, zarabiając kilkaset nędznych złotych jako kalkulator-chronometrażysta w jakiejś spółdzielni inwalidów (DO, s. 51).

18 M. Urbanek, op. cit., s. 175.

19 S. Cenckiewicz, P. Gontarczyk, Konfident $z$ wyboru, www.Wprost.pl/ar/91313/konfident-z-wyboru [dostęp: 13.10.2013].

20 M. Urbanek, op. cit., s. 161. 
Jednak zdecydowana większość ludzi, mimo deklarowanej sympatii, jest charakteryzowana na granicy plotkarstwa, dobrego smaku i negatywnego osądu, np. portret Jarosława Iwaszkiewicza odmalowany jest następująco:

Osobiście - bardzo lubię Iwaszkiewicza. Jest to pan postawny, bardzo uprzejmy, bardzo dobrze wychowany. [...] Potężnego wzrostu, o frapującej, oryginalnej twarzy, był w swoim życiu globtroterem i pederastą, dyplomatą i smakoszem, dobrym pisarzem i śmieszną figurą polityczną, indywidualnością i pionkiem. Po sześćdziesięciu latach jest albo sprzedawczykiem, albo głupcem. Tertium - niestety - non datur. A nie wiadomo, co lepsze (DO, s. 205).

Dotyczy to również tych nienależących do towarzystwa, o nieważnych nazwiskach, będących za to tkanką tego, co stanowi warszawską codzienność i jej specyficzny koloryt:

Przed południem byłem u mojego fryzjera. Jest to ponury cham, ale lubię go bardzo. Jest jednym z przedstawicieli ginącej inicjatywy prywatnej, ma malutki zakładzik w podwórzu na Chmielnej. Lubię atmosferę tego zawodu, pełną niegrzecznej, nieuprzejmej serdeczności, takiej „dla swoich klientów". Kiedy nikt nie czeka pod ścianą w kolejce, rozmawiamy o kobietach. To odświeża, takie vademecum seksualizmu przy strzyżeniu (DO, s. 50).

\section{Wątek kobiecy}

Kobiety, seks i miłość to elementy składowe najciekawszego chyba wątku dziennika Tyrmanda, którym pisarz składa hołd takimi słowy: „Kobiety zaś są bardziej interesujące od mężczyzn, ich życie zawiera w sobie problemy głębsze i większą głębię przeżywania niż życie większości mężczyzn, którzy żyją przeważnie ambicjami i urazami” (DO, s. 101).

Inga Iwasiów ${ }^{21}$, przedstawicielka nurtu feministycznej krytyki literackiej, proponuje przeczytać Dziennik 1954 jako prozę miłosną, dostrzegając w diariuszu Tyrmanda znakomity materiał na powieść psychologiczną o miłości (bo to, co nie starzeje się nigdy i zawsze jest aktualne, to ludzkie emocje). Określenie „wątek kobiecy”, użyte w tytule podrozdziału, może być jednak mylące: opisywane przez Tyrmanda postacie, uczucia i związki charakteryzują tyleż kobiety i ich role w ówczesnym społeczeństwie, co samego autora i jego wyobrażenie o kobiecości. Inga Iwasiów zauważa: „Najlepszymi statystami w teatrze budowania własnego wizerunku są oczywiście kobiety. Wynika to z przyjmowanego jako pewnik przeświadczenia o ich intelektualnej i emocjonalnej niższości"22. Tyrmand prowadzi swoiste studia kobiece, niemające jednak wiele wspólnego z tym, co kojarzy nam się ze współczesnym dorobkiem feminizmu. Woli wysłuchiwać te ładne: „Była u mnie L. Powiedziała, że przyszła po książki. Było to nieprawdą. Przyszła po swój kontyngent samooskarżeń. Usiadła - śliczna, smukła, przejrzysta - i przez

21 I. Iwasiów, Milczenie Bogny. O „Dzienniku 1954” Leopolda Tyrmanda, „Kresy” 1996, nr 1, s. $77-85$.

22 Ibidem, s. 79. 
godzinę opowiadała mi o sobie rzeczy najgorsze” (DO, s. 203), brzydszym nie poświęca wiele czasu, chyba że chodzi o skrytykowanie ustroju:

Są one [murarki - przyp. H.J.R.] uderzająco brzydkie, przy czym dowodzą sobą wielkiej prawdy życiowej: kobieta brzydka z natury i uciekająca dlatego od kobiecości staje się jeszcze brzydsza, razi swoją brzydotą. Nie wierzę, aby stojąca przy mnie murarka po przyjściu do domu, umyciu się i włożeniu ładnej sukienki wracała do kobiecości. To wykluczone. Trzy czwarte dnia, spędzone w spodniach przy ciężkiej, fizycznej pracy, infekują ją na resztę doby ową miksturą jaskiniowości i hermafrodytyzmu, która usuwa z niej kobiecość (DO, s. 180).

Ta obserwacja prowadzi do wniosku ogólnego: „[k]omunizm cofa koło historii, jest to dla mnie jasne i oczywiste w dziedzinie kultury, prawodawstwa, polityki, organizacji społecznej. W żadnej z tych dziedzin nie cofa się tak daleko jak na polu stosunków pomiędzy płciami” (DO, s. 180). Światopogląd Tyrmanda jest niezwykle patriarchalny, kobiety traktuje w gruncie rzeczy przedmiotowo, kreując się na romantycznego kochanka poszukującego tej jedynej:

Bałem się śmiertelnie zmarnowanego życia, bałem się, że jest już za późno. Może dlatego właśnie, że tak bardzo pożądałem jednej, jedynej kobiety — życie moje wypełniło się tłumem kobiet. Kobiety przeciekały mi przez ręce, tasowałem je jak talię kart, niektóre kochały mnie, inne przesuwały się przez moje miesiące, inne jeszcze przez tygodnie, jeszcze inne - tylko przez noce (DO, s. 271).

Tyrmand w kobietach przegląda się jak w lustrze, są mu niezbędne do zbudowania własnego wizerunku, uważa, że ma nad nimi władzę:

I znów konfesjonał. Przy stoliku, w modnym klubie. Nie wiem, co to oznacza, ale kobiety lubią dzielić się ze mną skłonnością do psychicznych obnażeń i upodobaniem do moralnych przepierek. [...] Bardzo często zwierzenia przeistaczają się, w mojej „praktyce”, w romans czy łóżkowy epizod, wiele kobiet zaczyna mówić z tą intencją od samego początku wynurzeń (DO, s. 101),

a w innym miejscu konstatuje nieco cynicznie:

Spotkałem na ulicy T. Ta dziewczyna natomiast mogłaby służyć za wzór bohaterki egzystencjalistycznej powieści. Czego się nie dotknie, rozsypuje jej się w rękach, każdy jej krok jest krokiem w nicość bez perspektyw. Kocha się w facecie, który ją zniszczył. Kiedy chciałem jej pomóc i wyrwać ją z tego, została moją kochanką, ale nie została ze mną (DO, s. 45).

Gwoli sprawiedliwości należy przyznać, że Tyrmand potrafi być liryczny i oprócz scen erotycznych, ocierających się o pornografię, w Dzienniku odnajdujemy i takie fragmenty:

Przed południem było tak samo. Sam nie wiem, kiedy się zaczęło, w mroźny, jasny, bladobłękitny dzień za oknem, ale było ślicznie. Kocham tę chwilę, gdy młode, głodne ciało zaczyna sycić się słodyczą odprężenia, ukojenia, przeżycia, a podłużne, nieco skośne, czarne oczy wśród pąsu policzków i bieli czoła błyszczą miękkim, radośnie znużonym spojrzeniem (DO, s. 65). 


\section{Zakończenie}

Ciekawiej i bardziej fascynująco jest, gdy pisarz nie opowiada o swoim życiu bezpośrednio, przedstawiając je takim, jakie było, ale żyje wedle tego, jak swoje życie opisał. Taki prymat autokreacji własnej biografii nad wiernością faktom występuje w Dzienniku 1954 bardzo wyraźnie. Leopold Tyrmand świadomie konstruuje opowieść o sobie, dziennik podlega procesowi upowieściowienia, a on sam nadaje określony egzystencjalny i literacki kształt swojemu życiu. Jak napisała Lidia Burska: „Największym osiągnięciem Leopolda Tyrmanda jest Leopold Tyrmand. Tyrmand - zjawisko, legenda, mistyfikator i mitotwórca, którego postać bardziej niż dzieło przyciąga uwagę czytelników"23. A może jednak do osiągnięć można zaliczyć nie tylko postać, lecz także dzieło, w tym przemyślany w każdym calu, kreujący siebie diariusz-powieść?

\section{Bibliografia}

Burska L., Tyrmand, [w:] Sporne postaci polskiej literatury współczesnej, red. A. Brodzka, L. Burska, Warszawa 1996.

Czermińska M., Leopold Tyrmand - głos świadka, „Rocznik Towarzystwa Literackiego im. Adama Mickiewicza” 1993.

Iwasiów I., Milczenie Bogny. O „Dzienniku 1954” Leopolda Tyrmanda, „Kresy” 1996, nr 1.

Iwasiów I., Opowieść i milczenie. O prozie Leopolda Tyrmanda, Szczecin 2000.

Głowiński M., Dzienniki z minionych lat, [w:] idem, Skrzydła i pięta, Kraków 2004.

Głowiński M., Powieść a dziennik intymny, [w:] idem, Narracje literackie i nieliterackie. Prace wybrane, t. II, Kraków 1998.

Kochańczyk A., Kłamstwo w dzienniku. O „Dzienniku 1954” Leopolda Tyrmanda, [w:] Literatura i komunikacja. Od listu do powieści autobiograficznej, red. A. Blain, Z. Maciejewski, Lublin 1998.

Kowalczyk M., Poetyka karnawału w Dzienniku 1954 Leopolda Tyrmanda, „Pamiętnik Literacki” 2006, z. 4.

Kowalczyk M., Tyrmand karnawałowy, Kraków 2008.

Niciński K., Dwie wersje „Dziennika 1954” Leopolda Tyrmanda. Wokół problemu tożsamości tekstu, „Pamiętnik Literacki” 2006, z. 4.

Pasterska J., Świat według Tyrmanda, Rzeszów 2000.

Przybylski R., O tym jak Leopold Tyrmand wałęsał się w świecie kultury popularnej, Poznań 1998.

Tyrmand L., Dziennik 1954, Londyn 1980.

Tyrmand L., Dziennik 1954, wersja oryginalna, wstęp H. Dasko, Warszawa 1999.

Urbanek M., Zły Tyrmand, Warszawa 2007.

Woźniakiewicz-Dziadosz M., Dokument osobisty wobec formy powieściowej, „Dziennik 1954” Leopolda Tyrmanda, [w:] eadem, Obrzeża formy powieściowej, Lublin 1998.

Zawrzykraj A., „Dziennik 1954” Leopolda Tyrmanda. Narracja jako narzędzie autokreacji, „Teksty Drugie" 2002, nr 1/2.

${ }^{23}$ L. Burska, Tyrmand, [w:] Sporne postaci polskiej literatury współczesnej, red. A. Brodzka, L. Burska, Warszawa 1996, s. 179. 


\section{Leopold Tyrmand. Writer's notebook: self-creation and the novel}

\section{Summary}

The paper "Leopold Tyrmand. Writer's notebook: self-creation and the novel" presents a colorful character in the landscape of post-war, communist Poland. The analysis focuses on "Diary 1954" and is conveyed using both current research and the critics' reviews of the author's contemporaries. The literary features exposed in this paper consist of self-creation, using members of the artistic community of that time as characters as well as the motif of an erotic relationship. Leopold Tyrmand consciously creates his own story; his diary becomes a novel, while his life story of his life is gaining literary shape. 